\title{
The Incidence of Adult Obesity is Associated with Parental and Adolescent Histories of Obesity in North Sumatra, Indonesia: A Cross-Sectional Study
}

\section{Dina Keumala Sari, (D) M Ichwan, ${ }^{2}$ Dewi Masyithah, ${ }^{3}$ Ridha Dharmajaya, ${ }^{4}$ Alfi Khatib ${ }^{5}$ \\ 'Department of Nutrition, Faculty of Medicine, Universitas Sumatera Utara, Medan, Indonesia; ${ }^{2}$ Department of Pharmacology, Faculty of Medicine, Universitas Sumatera Utara, Medan, Indonesia; ${ }^{3}$ Department of Parasitology, Faculty of Medicine, Universitas Sumatera Utara, Medan, Indonesia; ${ }^{4}$ Department of Neurosurgery, Faculty of Medicine, Universitas Sumatera Utara, Medan, Indonesia; ${ }^{5}$ Kulliyah of Pharmacy, International Islamic University Malaysia, Kuala Lumpur, Malaysia}

\section{Video abstract}

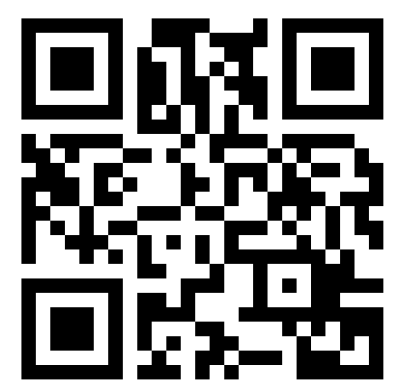

Point your SmartPhone at the code above. If you have a QR code reader the video abstract will appear. Or use: https://youtu.be/XQsODh_2jKE

Correspondence: Dina Keumala Sari Department of Nutrition, Faculty of Medicine, Universitas Sumatera Utara, Jl. Dr. Mansyur No. 5, Padang Bulan, Kec. Medan Baru, Kota Medan, Sumatera Utara, Medan, 20155, Indonesia

Tel +62 8I397I77693

Emaildina@usu.ac.id
Purpose: Obesity that occurs in adulthood is influenced by various factors, not only energy balance, especially concerning the amount of energy consumed, but also heredity. The hereditary factors of obese parents on childhood obesity have been studied, but what about adulthood? This study examines the relationship between a history of obesity in adolescence, and maternal and paternal incidences of adult obesity.

Patients and Methods: This study was a cross-sectional study that included adult men and women aged 20-60 years old. The subjects had no chronic or metabolic disease. This research was conducted from April to November, 2020, in North Sumatra Province, Indonesia. The parameters studied were demographics, daily food intake, anthropometry and a history of obesity in adolescence, and for the participants' fathers and mothers. The statistical test used was the chi-squared test/Fisher test.

Results: This study included 136 research subjects, 60 male and 76 female; based on the results of the study, $47.8 \%$ were found to be obese, but food intake showed a low intake (96.2\%). There was a significant relationship between a history of obesity in adolescence and incidences of obesity $\left(\geq 30 \mathrm{~kg} / \mathrm{m}^{2}\right)$ in the mother and father, with significance values of $p=0.01, p=0.004$, and $p=0.001$, respectively.

Conclusion: This study found that there was a significant relationship between a history of obesity in adolescence and incidences of adult obesity $\left(\geq 30 \mathrm{~kg} / \mathrm{m}^{2}\right)$ in parents, but not with the level of food intake per day. The risk of obesity will increase further with a history of obesity in parents and obesity in adolescence, and this can be used to understand and prevent obesity.

Keywords: adolescent, energy, food, heredity, anthropometry

\section{Introduction}

The overall increase in obesity worldwide has not only occurred in developed countries; this increase has also been experienced by developing countries such as those in Asia. ${ }^{1}$ It is estimated that there will be an increase in obesity cases every year. ${ }^{1,2}$ Weight gain during growth, especially adolescence, can lead to obesity in adulthood. ${ }^{3,4}$ However, previous studies that have examined obesity in adolescence were influenced by diet and by a history of obesity in parents. ${ }^{3}$ This is controlled by the obesity gene that parents pass down. ${ }^{5}$

The prevalence of obesity in children globally, especially in Asia, is increasing. ${ }^{1}$ The increase is estimated to be more than $30 \%$, especially in developing countries 
compared to developed countries. ${ }^{1,6,7}$ Cases of obesity are also more common in urban areas than in rural areas. ${ }^{1,8}$ Overweight and obesity are defined as excess fat accumulation that poses a dangerous health risk. ${ }^{6,9}$ A body mass index of more than $25 \mathrm{~kg} / \mathrm{m}^{2}$ is expressed as overweight, and more than $30 \mathrm{~kg} / \mathrm{m}^{2}$ is declared as obese. ${ }^{1}$ However, in AsiaPacific countries, the criteria for obesity are set as the body mass index being more than $25 \mathrm{~kg} / \mathrm{m}^{2}{ }^{10}$ The rate at which obesity is increasing has more than quadrupled, from $4 \%$ to $18 \%$ since 1975 , not only in high-income countries, but also in low- and middle-income countries. ${ }^{1,8}$ The prevalence of obesity is increasing in major cities in Indonesia, including in North Sumatra, where the prevalence rate of obesity has reached $30 \%{ }^{11}$

Obesity is closely related to the accumulation of fat in the abdomen, namely, abdominal visceral fat, which causes the dysregulation of fatty acid metabolism, which later becomes key for type 2 diabetes mellitus. ${ }^{6,12,13}$ Therefore, obesity studies are vital in order to develop understandings of health and prevent obesity in the future. The increase in body weight during adolescence will determine obesity in adulthood; this is a determining factor because obese adolescents tend to become obese adults. ${ }^{3}$ Furthermore, if obesity occurs in adulthood, it will be easier for non-communicable diseases such as diabetes, cardiovascular disease, and complications of other metabolic disorders to occur. ${ }^{3-5}$

Previous research has shown that there is a relationship between obesity in adolescence and obesity in adulthood. ${ }^{4,14-16}$ In addition to a history of obesity in adolescence, the obesity gene inherited by parents is closely related to the likelihood of a person being obese compared with adolescents who have parents with a history of being a normal weight. ${ }^{17-20}$ Previous research reported that there is an influence of maternal obesity on dietary fat intake in children, suggesting that mothers may contribute to the development of obesity in children by influencing their dietary fat intake. ${ }^{4}$ This research also explored how dietary fat intakes contribute to obesity in boys, independent of physical activity energy expenditure. ${ }^{4}$ There were also associations between a family history of diabetes (FHD) in children and adolescents, which remained strong for girls and boys. ${ }^{15,16}$ However, other research has reported that parents' own obesity-related behaviors are factors that may affect their confidence to support their child's behavioral changes. ${ }^{14}$ Therefore, actors seeking to prevent childhood obesity should address parent/family behaviors as part of their obesity prevention strategies. ${ }^{14}$
The development of obesity prevention techniques needs to be emphasized. The role of genes, especially obesity genes inherited from parents, can be a target for preventing obesity in adulthood. ${ }^{5}$ In addition, the role of parents in preventing obesity is needed, especially in forming children's habits. ${ }^{14,21,22}$ Based on various studies, it can be seen that there is a role of genes inherited by the father or mother in the occurrence of obesity in children, in addition to obesity which occurs in adolescence also determining the occurrence of obesity in adulthood. These factors can be studied and observed along with the increasing prevalence of obesity in Asian countries; thus, this study aimed to find the relationship between a history of obesity in adolescence and parents with a history of adult obesity. The results of this study are expected to provide an understanding of preventing obesity through socialization, communicating the importance of maintaining a normal body weight during adolescence.

\section{Methods}

\section{Study Design}

This study included a cross-sectional design that took sociodemographic data (ie, age, sex, occupation, adolescent history, history obesity of father and mother), anthropometric examinations (ie, body mass index and abdominal circumference), and examinations of daily food intake (ie, energy, fat, protein, and carbohydrate intakes per day) in the study subjects. This study included the incidence of adult obesity as a dependent variable, with parental and adolescent histories of obesity as independent variables.

All research subjects were recruited from the same region, in rural areas in North Sumatera and Medan City, Sumatra Island, Indonesia. This research was conducted from April to July, 2020, after the COVID-19 pandemic had spread across the globe; the data collection was carried out with the implementation of strict health protocols.

\section{Participants}

The included research subjects were healthy men and women aged 20-60 years old; the exclusion criteria included pregnant women, nursing mothers, impaired kidney and liver functions, chronic disease, or other metabolic disorders. Research subjects were sampled randomly at existing public health centers. The dissemination of information was performed through counseling about the importance of maintaining health by maintaining 
a normal weight to prevent obesity. The research subjects volunteered willingly, with the number of subjects gathered being 153 subjects, although after applying the exclusion criteria, 136 subjects were included in the criteria and data analysis.

\section{Statistical Analysis}

Data were analyzed using version 11.5 of the IBM-SPSS statistical program (IBM Corp., Chicago, IL). Categorical variables were expressed as percentages. Normally distributed continuous variables were expressed as the mean \pm $\mathrm{SD}$, whereas non-normally distributed continuous variables were expressed as medians (minimum-maximum). The tests were performed to identify whether there was a relationship between a history of obesity in adolescence and parents with a history of obesity, using the chi-squared test; however, if this did not meet the requirements, Fisher's test was used.

\section{Sample Size and Power Calculation}

This study aimed to prove the research hypothesis that there is a relationship between a history of obesity in adolescence, as well as parents with a history of obesity. To determine the minimum sample size in each two-tailed hypothesis test, this study had a significance level of 0.05 ( $\alpha$-value) and $80 \%$ power ( $\beta$-value). This study calculated all hypotheses and took the largest sample size. This study used a purposive sampling method, which is a sampling technique based on the researcher's considerations regarding which samples are the most appropriate, useful and considered to be representative of a population.

\section{Parental and Adolescent's History}

This study used a questionnaire completed by the participants, which collected data pertaining to age, gender, ethnicity, a history of obesity in parents, and a history of obesity in adolescence. This research used a retrospective approach, where effects were identified at this time; then, risk factors are identified as existing or having occurred in the past.

\section{Anthropometric Examination}

Anthropometry included height (to the nearest $0.5 \mathrm{~cm}$ ), weight (to the nearest $0.1 \mathrm{~kg}$ ), and body mass index (calculated as $\mathrm{kg} / \mathrm{m}^{2}$ ). The categorized body mass index (BMI) was based on the World Health Organization (WHO) guidelines for the general population, which are $<18.5 \mathrm{~kg} / \mathrm{m}^{2}$ classified as underweight; $18.5-24.9 \mathrm{~kg} / \mathrm{m}^{2}$ classified as normal weight; $25-29.9 \mathrm{~kg} / \mathrm{m}^{2}$ classified as overweight/at risk; and $>30 \mathrm{~kg} / \mathrm{m}^{2}$ classified as obese. ${ }^{10}$ The assessment of obesity based on the World Health Organization criteria is applied globally, namely, $\geq 30 \mathrm{~kg} /$ $\mathrm{m}^{2}$; the criteria for the association analysis were obese and not obese. ${ }^{1}$ We examined waist circumference using a standardized measuring tape, in centimeters. The category of abdominal circumference was different between men and women. For men, less than $90 \mathrm{~cm}$ was classified as normal, and more than $90 \mathrm{~cm}$ was classified as central obesity. For women, an abdominal circumference of less than $80 \mathrm{~cm}$ was classified as normal, and that more than or equal to $80 \mathrm{~cm}$ was classified as central obesity. ${ }^{10}$

\section{Nutrient Intake Assessment}

Assessments of nutrient intakes were based on food recall for two days (one weekday and one day), including energy, protein, fat, and carbohydrate intakes, and the percentage of fulfilment according to the Indonesian Recommended Dietary Allowances (RDA) 2019. ${ }^{23}$ The questionnaire was conducted using the Nutrisurvey application (2005), which included Indonesian foods. ${ }^{24}$

The following categorizations were determined: for calorie intake, $<2500$ calories per day was low and $\geq 2500$ calories per day was average; for protein intake, $<60$ grams per day was low and $\geq 60$ grams per day was average; for carbohydrate intake, $<400$ grams per day was low and $\geq 400$ grams per day was average; for fat intake, $<65$ grams per day was low and $\geq 65$ grams per day was average; for fiber intake, $<25$ grams per day was low and $\geq 25$ grams per day was average; and for vitamin D intake, $<15$ micrograms per day was low and 15 micrograms per day was average. ${ }^{23,24}$

\section{Ethics Approval and Consent to Participate}

This study was conducted according to the guidelines laid down in the Declaration of Helsinki, and all methods/ procedures involving research study participants were registered with ClinicalTrials.gov (NCT04650308) with a registration date of November 18, 2020. This study was also approved by the Universitas Sumatera Utara Ethical Committee. This research procedure and protocol were approved by the Research Ethics Committee of the University of North Sumatra, Indonesia, with the certificate number: No. 61/KEP/USU/2020. All participants knowingly consented to participate in this study; the 
research subjects read the explanation about the research and indicated their willingness to take part by signing an informed consent form.

\section{Results}

This study included 136 research subjects, with primary data collected including the characteristics of the research subjects and data on the history of obesity in parents and adolescence. Anthropometric data were used for direct anthropometric measurements and assessments for food intake data were performed by interviewing the research subjects. In addition, an assessment of food intake was carried out with the help of food models and pictures of food ingredients to help research subjects remember the amount of food consumed.

Table 1 shows the basic characteristics of the research subjects, with the highest percentage for age being those in the $41-50$ years group $(32.4 \%)$. The youngest participant in this study was 20 years old, and the oldest was 58 years old. The distribution of sex was almost evenly distributed between men and women, although the percentage of women was slightly higher than that of men. The distribution of those working as housewives was found to be higher than other occupations, and the lowest percentage was working as a teacher. Most of the research subjects had a Senior High School education; only a small proportion had achieved a master's degree (Table 1).

Table 2 shows the distribution of the research subjects with the global WHO obesity body mass index criterion of $30 \mathrm{~kg} /$ $\mathrm{m}^{2}$, according to which as many as $11 \%$ were obese. Table 2 shows that based on the abdominal circumference criteria, the female group was included in the category with an abdominal circumference of more than $80 \mathrm{~cm}(50 \%)$. In contrast, a low percentage was found for an abdominal circumference of less than $90 \mathrm{~cm}$ in the male group. Abdominal circumference was moderately correlated with body mass index $(p=0.001, \mathrm{r}$ : 0.419) through Pearson's analysis.

The daily food intakes are shown in Table 3. This information indicates that the intakes of energy, fat, protein, carbohydrates, and fiber are not correlated with the recommended nutritional adequacy rate. Regarding vitamin D intake, most of the study subjects reported a more than healthy intake per day (51.5\%). All study subjects reported a carbohydrate intake of fewer than 400 grams per day, which was very low. There was no correlation between whole food intake and body mass index.

Table 4 reports significant relationships between a history of obesity in adolescence and a history of obesity in parents,
Table I Socio-Demographic Data of All Subjects

\begin{tabular}{|c|c|}
\hline Characteristics & n (\%) \\
\hline \multicolumn{2}{|l|}{ Age (years) } \\
\hline $20-30$ & $26(19.1)$ \\
\hline $31-40$ & $36(26.5)$ \\
\hline $4 I-50$ & $44(32.4)$ \\
\hline $51-60$ & $30(22.1)$ \\
\hline Age (mean $\pm S D$ ), years & $40.49 \pm 10.89$ \\
\hline \multicolumn{2}{|l|}{ Gender } \\
\hline Male & $60(44.1)$ \\
\hline Female & $76(55.9)$ \\
\hline \multicolumn{2}{|l|}{ Occupation } \\
\hline Housewife & $48(35.3)$ \\
\hline Labour & $39(28.7)$ \\
\hline Farmer & $19(14.0)$ \\
\hline Government staff & $17(12.5)$ \\
\hline Teacher & $13(9.5)$ \\
\hline \multicolumn{2}{|l|}{ Education } \\
\hline Master Degree & $4(2.9)$ \\
\hline Bachelor Degree & $16(11.8)$ \\
\hline Senior High School & $89(65.4)$ \\
\hline Junior High School & $18(13.2)$ \\
\hline \multicolumn{2}{|l|}{ Comorbidities } \\
\hline No comorbidities & 81 (59.6) \\
\hline Dispepsia & $31(22.8)$ \\
\hline High blood pressure & $13(9.6)$ \\
\hline Hypercholesterolemia & $9(6.6)$ \\
\hline Alergy & $2(1.5)$ \\
\hline \multicolumn{2}{|l|}{ Supplement intake } \\
\hline No & II $15(84.6)$ \\
\hline Yes & $21(15.4)$ \\
\hline
\end{tabular}

Notes: Age data presented in mean \pm standard deviation (SD). Others presented in number of the subject and percentage.

with the criteria for obesity of weighing over $30 \mathrm{~kg} / \mathrm{m}^{2}$. This study indicates that there is a significant relationship between obesity in adolescence and parents with an incidence of adult obesity. The high body mass indexes (obesity criterion of more than $30 \mathrm{~kg} / \mathrm{m}^{2}$ ) indicate that the probability factor had no relationship between a history of obesity in adolescence and parents with incidences of adult obesity was less than $5 \%$, and the result is significant. This significance showed more value in maternal and paternal obesity history compared to the history of obesity in adolescence.

Female research subjects exhibited significant relationships with a history of maternal, paternal and adolescent obesity ( $p=0.001, p=0.001$, and $p=0.027$, respectively); the association with maternal obesity was highly significant. 
Table 2 Characteristic Data of the Subjects Based on Anthropometry Status

\begin{tabular}{|c|c|c|}
\hline $\begin{array}{l}\text { Characteristics of } \\
\text { Anthropometry Status }\end{array}$ & Mean \pm SD & n (\%) \\
\hline Height $(\mathrm{cm})$ & $155.55 \pm 12.73$ & \\
\hline Weight (kg) & $61.13 \pm 10.28$ & \\
\hline Body mass index $\left(\mathrm{kg} / \mathrm{m}^{2}\right)$ & $26.59 \pm 10.79$ & \\
\hline \multicolumn{3}{|l|}{ Categorized, n(\%): } \\
\hline Underweight & & $7(5.1)$ \\
\hline Normal & & $64(47.1)$ \\
\hline Overweight & & $50(36.8)$ \\
\hline Obese & & $15(11.0)$ \\
\hline Waist circumference $(\mathrm{cm})$ & $82.85 \pm 11.39$ & \\
\hline Male & $84.28 \pm 10.48$ & \\
\hline \multicolumn{3}{|l|}{ Categorized, n(\%): } \\
\hline$<90 \mathrm{~cm}$ & & $47(78.3)$ \\
\hline$>90 \mathrm{~cm}$ & & $13(2 \mid .7)$ \\
\hline Female & $81.72 \pm 12.02$ & \\
\hline \multicolumn{3}{|l|}{ Categorized, n(\%): } \\
\hline$<80 \mathrm{~cm}$ & & $38(50)$ \\
\hline$>80 \mathrm{~cm}$ & & $38(50)$ \\
\hline
\end{tabular}

Notes: Numeric data were presented in mean and standard deviation. Categorical data were presented in number of the subject and percentage.

At the same time, male research subjects showed a significant relationship with a history of paternal obesity $(p=0.03)$, whereas a history of maternal obesity and adolescence did not reveal significant relationships $(p=0.631$ and $p=0.247$, respectively).

\section{Discussion}

This study explored the relationships between a history of obesity in adolescence, as well as mothers and fathers with a history of adult obesity. Based on the results of this study, the main findings were: (1) there is a significant relationship between a history of obesity in adolescence, a history of obesity in the father, and a history of obesity in the mother and an incidence of adult obesity in the subject; and (2) histories of obesity in the mother, father, and in adolescence revealed a significant relationship in female subjects, but only father's obesity history revealed an association in male subjects.

Previous research has shown that parental obesity is a predictor of childhood overweight. ${ }^{20,25-27}$ The family risk ratio contributing to childhood obesity is when one parent reaches $>2.5 .^{5,17}$ Birth weight is characterized by
Table 3 Characteristic Data of the Subjects Based on Nutrient Intake

\begin{tabular}{|c|c|c|}
\hline $\begin{array}{l}\text { Characteristics of Food } \\
\text { Intake Per Day }\end{array}$ & Mean士SD & $n(\%)$ \\
\hline $\begin{array}{l}\text { Energy intake }(\mathrm{Cal}) \\
\text { Categorized, } \mathrm{n}(\%) \text { : } \\
\text { Less than } 2500 \mathrm{kal} / \text { day } \\
\text { More than } 2500 \mathrm{kal} / \text { day }\end{array}$ & $1255.39 \pm 744.35$ & $\begin{array}{c}126(92.6) \\
10(7.4)\end{array}$ \\
\hline $\begin{array}{l}\text { Fat intake (gram) } \\
\text { Categorized, } \mathrm{n}(\%) \text { : } \\
\text { Less than } 65 \mathrm{gram} / \text { day } \\
\text { More than } 65 \mathrm{gram} / \text { day }\end{array}$ & $41.13 \pm 33.45$ & $\begin{array}{l}115(84.6) \\
21(15.4)\end{array}$ \\
\hline $\begin{array}{l}\text { Protein intake (gram) } \\
\text { Categorized, } \mathrm{n}(\%) \text { : } \\
\text { Less than } 60 \mathrm{gram} / \text { day } \\
\text { More than } 60 \mathrm{gram} / \text { day }\end{array}$ & $49.14 \pm 23.55$ & $\begin{array}{c}105(77.2) \\
31(22.8)\end{array}$ \\
\hline $\begin{array}{l}\text { Carbohydrate intake (gram) } \\
\text { Categorized, n(\%): } \\
\text { Less than } 400 \text { gram/day } \\
\text { More than } 400 \text { gram/day }\end{array}$ & $41.13 \pm 33.45$ & $\begin{array}{c}136(100) \\
0\end{array}$ \\
\hline $\begin{array}{l}\text { Fiber intake (gram) } \\
\text { Categorized, } \mathrm{n}(\%) \text { : } \\
\text { Less than } 25 \text { gram/day } \\
\text { More than } 25 \text { gram/day }\end{array}$ & $8.91 \pm 6.48$ & $\begin{array}{c}134(98.5) \\
2(1.5)\end{array}$ \\
\hline $\begin{array}{l}\text { Vitamin D intake (microgram) } \\
\text { Categorized, } \mathrm{n}(\%) \text { : } \\
\text { Less than } 15 \mathrm{microgram} / \text { day } \\
\text { More than } 15 \text { microgram/day }\end{array}$ & $17.40 \pm 13.16$ & $\begin{array}{l}66(48.5) \\
70(51.5)\end{array}$ \\
\hline
\end{tabular}

Notes: Numeric data were presented in mean and standard deviation. Categorical data were presented in number of the subject and percentage.

$30 \%$ genetic heritability; this effect is significant, based on the genetic influences of the mother and father. $4,5,17,28,29$ However, obesity genes, or so-called obesogenic genes, that mothers and fathers inherit are predictors of obesogenic behavior in an obesogenic environment. ${ }^{5}$ This study also presents a relationship between a history of obesity in parents and obesity in adulthood, although it was found that food intake was no more than the recommended daily nutritional adequacy rate.

Calorie intake for participants in this study revealed an intake of fewer than 2500 calories per day. The percentage of obesity in adulthood was still found; a history of obesity in parents and obesity in adolescence may influence this. This study found that a person is born carrying the obesity gene from his parents, from the father, the mother, or both. The magnitude of the influence of one parent being obese is $40 \%$, and $80 \%$ if both are obese. ${ }^{4}$ 
Table 4 Association Between Parental and Adolescent's History of Obesity and Adulthood Obesity

\begin{tabular}{|c|c|c|c|c|}
\hline \multicolumn{2}{|l|}{ Obesity History } & \multicolumn{2}{|c|}{ Obesity n (\%) } & \multirow[t]{2}{*}{$p$} \\
\hline & & No & Yes & \\
\hline Adolescent's obesity history n(\%) & $\begin{array}{l}\text { No } \\
\text { Yes }\end{array}$ & $\begin{array}{l}84(61.8) \\
37(27.2)\end{array}$ & $\begin{array}{c}5(3.7) \\
10(7.4)\end{array}$ & $0.006 *$ \\
\hline Mother's obesity history n(\%) & $\begin{array}{l}\text { No } \\
\text { Yes }\end{array}$ & $\begin{array}{l}92(67.6) \\
29(21.3)\end{array}$ & $\begin{array}{l}6(4.4) \\
9(6.6)\end{array}$ & $0.003^{*}$ \\
\hline Father's obesity history n(\%) & $\begin{array}{l}\text { No } \\
\text { Yes }\end{array}$ & $\begin{array}{c}106(77.9) \\
15(11.0)\end{array}$ & $\begin{array}{l}6(5.5) \\
9(6.6)\end{array}$ & $0.00 I^{*}$ \\
\hline
\end{tabular}

Notes: Association between parental's obesity history, adolescent's obesity history and incidence of adult obesity using using Fisher's test. *significant; $p<0.05$.

This study shows that the influence of a history of maternal obesity in women is more significant than that of father obesity or adolescent obesity. Meanwhile, in males, it is the history of father obesity which is relevant. There is no effect on the history of maternal obesity and childhood obesity. These findings are necessary as factors that must be understood and addressed, especially when dealing with cases of obesity in women and men. Previous research only assigned a relationship between the likelihood of a person being obese based on a history of obesity in parents but did not differentiate between men and women. ${ }^{19,20,25,30}$

Furthermore, the obesity gene is influenced by an obesogenic environment; however, most critical is the parents' role in passing on the obesity gene and raising the child in an obesogenic environment until they enter adolescence. If obesity develops in adolescence, the likelihood of becoming obese in adulthood will be greater. For this reason, understanding the relationship between these factors must be properly considered so that obesity prevention programs can be successful.

Previous research has stated that mothers play a role in obesity in adolescence through the intake of fast foods, and fat intake plays a role in obesity in boys independent of physical activity. ${ }^{2,4,5,12}$ Furthermore, discussions on this matter have been developed by other researchers, who stated that there was a close relationship between childhood obesity and adult obesity. ${ }^{3}$ This risk factor can be prevented through behavior modifications and clinical therapy. A healthy lifestyle needs to be maintained in the family and community; this needs to be applied to reduce the prevalence of childhood obesity and its effects in adulthood.

Another important effect is the occurrence of cardiovascular disease, which increases morbidity and mortality. $6,7,9,20$ Obese children may have risk factors detrimental to cardiovascular health with cardiovascular comorbidities such as dyslipidemia, which manifests as an increase in lowdensity lipoprotein (LDL) levels. ${ }^{2,3,6}$ Previous studies have also reported a direct relationship between body mass index and cardiovascular disease. ${ }^{18,28,31}$ Abdominal circumference (central obesity) is not only related to body mass index; it also influences the occurrence of metabolic disorders, which are related to the occurrence of type 2 diabetes mellitus. ${ }^{6,12}$ The epidemic of childhood obesity has been linked with an increase in the prevalence of coronary artery disease in young and middle-aged adults. ${ }^{3,6,31}$ It is estimated that the prevalence of coronary artery disease could increase by 5 $16 \%$ by $2035 ., 31$

This study had some bias, which was interview bias in nutrient assessment analyses, although food models were used and a nutritionist interviews the study subjects. This could have reduced the bias in this study. This study also had limitations, namely, not performing obesity gene examinations, which would have provided a more meaningful insight. In addition, this study did not examine excess fat mass. Therefore, this study could only identify significant relationships and could not establish a relationship with deeper discussions of the factors involved.

\section{Conclusions}

This study found a significant relationship between a parent's history of obesity, adolescent obesity, and the incidence of adult obesity $\left(\geq 30 \mathrm{~kg} / \mathrm{m}^{2}\right.$ ). In women, the factors related to the incidence of adult obesity were a history of maternal obesity and adolescence. However, in men, the factor associated with an incidence of adult obesity was a history of paternal obesity. Therefore, obesity risk factors can be used to understand the prevention of obesity in order to reduce the overall incidence of the condition. 


\section{Data Sharing Statement}

The authors confirm that the data supporting the findings of this study are available within the article.

\section{Acknowledgments}

We would like to thank the local government of North Sumatera and Universitas Sumatera Utara for the grants.

\section{Author Contributions}

All authors made a significant contribution to this study, whether in the conception, study design, execution, acquisition of data, analysis and interpretation, or in all these areas; the drafting, revising or critically reviewing of the article; giving final approval of the version to be published; agreeing on the journal to which the article has been submitted; and agreeing to be accountable for all aspects of the work.

\section{Funding}

This project was funded, in part, by the Lembaga Penelitian Universitas Sumatera Utara according to TALENTA Universitas Sumatera Utara, year 2020, no. 4142/UN5.1.R/PPM/2020, date: 27 April 2020.

\section{Disclosure}

The authors report no conflicts of interest or financial interest in this work.

\section{References}

1. WHO. Obesity; 2021, Available from: https://www.who.int/healthtopics/obesity\#tab=tab_1. Accessed June 2, 2021.

2. Meyer JF, Larsen SB, Blond K, et al. Associations between body mass index and height during childhood and adolescence and the risk of coronary heart disease in adulthood: a systematic review and meta-analysis. Obes Rev. 2021:e13276. doi:10.1111/obr.13276

3. Raghuveer G. Lifetime cardiovascular risk of childhood obesity. Am J Clin Nutr. 2010;91(5):1514S-1519S. doi:10.3945/ajen.2010.28701D

4. Nguyen V, Enette Larson D, Rachel K, et al. Fat intake and adiposity in children of lean and obese parents. Am J Clin Nutr. 1995;63:507-513. doi:10.1093/ajen/63.4.507

5. Bouchard C. Childhood obesity: are genetic differences involved? Am J Clin Nutr. 2009;89(5):1494S-1501S. doi:10.3945/ajcn.2009.27113C

6. Yayun L, Yang H, Zhiyue X, et al. Association Between Different Obesity Patterns and the Risk of Developing Type 2 Diabetes Mellitus Among Adults in Eastern China: a Cross-Sectional Study. Diabetes Metab Syndrome Obesity. 2021;14:2631-2639. doi:10.2147/DMSO. S309400

7. Ziser K, Decker S, Stuber F, et al. Barriers to Behavior Change in Parents With Overweight or Obese Children: a Qualitative Interview Study. Front Psychol. 2021;12:631678. doi:10.3389/ fpsyg.2021.631678

8. Shen C, Zhou Z, Lai S, et al. Urban-rural-specific trend in prevalence of general and central obesity, and association with hypertension in Chinese adults, aged 18-65 years. BMC Public Health. 2019;19:661. doi:10.1186/s12889-019-7018-4
9. Hou X, Liu Y, Huijuan L, et al. Ten-year changes in the prevalence of overweight, obesity and central obesity among the Chinese adults in urban Shanghai, 1998-2007 - comparison of two cross-sectional surveys. BMC Public Health. 2013;13:1064-1072. doi:10.1186/14712458-13-1064

10. WHO. The Asia-Pacific perspective: redefining obesity and its intervention. Health Communications Australia Pte Limited. Australia; 2000. Available from: http://wwwdiabetes.com.au/pdf/obe sity_report.pdf. Accessed June 2, 2021

11. RI K. RISKESDAS 2018: Laporan Provinsi Sumatera Utara. Medan, North Sumatra: Lembaga Penerbit Balitbangkes; 2019.

12. Niu J, Seo DC. Central obesity and hypertension in Chinese adults: a 12-year longitudinal examination. Prev Med. 2014;62:113-118. doi:10.1016/j.ypmed.2014.02.012

13. Du T, Sun X, Yin P, et al. Increasing trends in central obesity among Chinese adults with normal body mass index, 1993-2009. Pediatr Diabetes. 2013;13:327-335. doi:10.1186/1471-2458-13-327

14. Arsenault LN, Xu K, Taveras EM, et al. Parents' obesity-related behavior and confidence to support behavioral change in their obese child: data from the STAR study. Acad Pediatr. 2014;14(5):456-462. doi:10.1016/j.acap.2014.03.001

15. Rodriguez-Moran M, Guerrero-Romero F, Aradillas-Garcia C, et al. Obesity and family history of diabetes as risk factors of impaired fasting glucose: implications for the early detection of prediabetes. Pediatr Diabetes. 2010;11:331-336. doi:10.1111/j.13995448.2009.00590.x

16. Romero-Ibarguengoitia ME, Vadillo-Ortega F, Caballero AE, et al. Family history and obesity in youth, their effect on acylcarnitine/ aminoacids metabolomics and non-alcoholic fatty liver disease (NAFLD). Structural equation modeling approach. PLoS One. 2018;13:e193138. doi:10.1371/journal.pone.0193138

17. Lee JH, Reed DR, Price RA. Familial risk ratios for extreme obesity: implications for mapping human obesity genes. Int $J$ Obes Relat Metab Disord. 1997;21(10):935-940. doi:10.1038/sj.ijo.0800498

18. Gunnell DJ, Frankel SJ, Nanchahal K, et al. Childhood obesity and adult cardiovascular mortality: a 57-y follow-up study based on the Boyd Orr cohort. Am J Clin Nutr. 1998;67(6):1111-1118. doi:10.1093/ajen/67.6.1111

19. Corica D, Aversa T, Valenzise M, et al. Does Family History of Obesity, Cardiovascular, and Metabolic Diseases Influence Onset and Severity of Childhood Obesity? Front Endocrinol (Lausanne). 2018;9:187. doi:10.3389/fendo.2018.00187

20. Sull JW, Kim S, Jee SH. Effects of Obesity and Family History of Diabetes on the Association of CETP rs6499861 with HDL-C Level in Korean Populations. J Lipid Atheroscler. 2019;8:252-257. doi:10.12997/jla.2019.8.2.252

21. Chung CJ, Huang YG. Predictive factors for accuracy of perception of parents regarding their overweight or obese children in Taiwan. Asia Pac J Clin Nutr. 2016;25:571-577. doi:10.6133/ apjen.092015.18

22. Davidson K, Vidgen H. Why do parents enrol in a childhood obesity management program?: a qualitative study with parents of overweight and obese children. BMC Public Health. 2017;17(1):159. doi:10.1186/s12889-017-4085-2

23. RI PMK. Angka Kecukupan Gizi bagi Bangsa Indonesia. Indonesia KKR, editor. Jakarta: Kementerian Kesehatan RI; 2019. 33.

24. Erhardt DJ. Nutrition Surveys and Calculation. Gross, Dr. Rainer; 2010.

25. Cederberg H, Stancakova A, Kuusisto J, et al. Family history of type 2 diabetes increases the risk of both obesity and its complications: is type 2 diabetes a disease of inappropriate lipid storage? J Intern Med. 2015;277(5):540-551. doi:10.1111/joim.12289

26. Reuter CP, Burgos MS, Bernhard JC, et al. Association between overweight and obesity in schoolchildren with rs9939609 polymorphism (FTO) and family history for obesity. J Pediatr (Rio J). 2016;92 (5):493-498. doi:10.1016/j.jped.2015.11.005 
27. Manios Y, Moschonis G, Karatzi K, et al. Large proportions of overweight and obese children, as well as their parents, underestimate children's weight status across Europe. The ENERGY (EuropeaN Energy balance Research to prevent excessive weight Gain among Youth) project. Public Health Nutr. 2015;18(12):2183-2190. doi:10.1017/S136898001400305X

28. Baker JL, Olsen LW, Sorensen TI. Childhood body-mass index and the risk of coronary heart disease in adulthood. $N$ Engl $\mathrm{J} \mathrm{Med}$. 2007;357:2329-2337. doi:10.1056/NEJMoa072515

29. Must A, Jacques PF, Dallal GE, et al. Long-term morbidity and mortality of overweight adolescents. A follow-up of the Harvard Growth Study of 1922 to 1935. $N$ Engl J Med. 1992;327 (19):1350-1355. doi:10.1056/NEJM199211053271904
30. Saunders TJ, Tremblay MS, Mathieu ME, et al. Associations of sedentary behavior, sedentary bouts and breaks in sedentary time with cardiometabolic risk in children with a family history of obesity. PLoS One. 2013;8:e79143. doi:10.1371/journal. pone. 0079143

31. Bibbins-Domingo K, Coxson P, Pletcher MJ, et al. Adolescent overweight and future adult coronary heart disease. $N$ Engl J Med. 2007;357(23):2371-2379. doi:10.1056/NEJMsa073166

\section{Publish your work in this journal}

The Journal of Multidisciplinary Healthcare is an international, peerreviewed open-access journal that aims to represent and publish research in healthcare areas delivered by practitioners of different disciplines. This includes studies and reviews conducted by multidisciplinary teams as well as research which evaluates the results or conduct of such teams or healthcare processes in general. The journal covers a very wide range of areas and welcomes submissions from practitioners at all levels, from all over the world. The manuscript management system is completely online and includes a very quick and fair peer-review system. Visit http://www.dovepress.com/testimonials. php to read real quotes from published authors. 